\title{
INTERRELATIONSHIP BETWEEN INVENTORY MANAGEMENT AND RETURN ON EQUITY: AN EMPIRICAL ASSESSMENT OF SRI LANKAN BEVERAGE, FOOD AND TOBACCO SECTOR LISTED COMPANIES
}

\author{
V. Sritharan \\ University of Jaffna, Sri Lanka, \\ vinasithambysri@univ.jfn.ac.lk
}

\begin{abstract}
A crucial role plays by Inventory management in balancing the cost and benefits linked with holding inventory. In the inventory management literature, several studies have been carried out regarding maintaining inventory level in a firm has been widely studied even though still there is contradiction in viewing inventory as both an asset and a liability. Few of those studies on the microeconomic determinants and consequences of inventories are somewhat inconsistent, thus this study take intention to test this issue with Beverage Food and Tobacco sector listed Companies. The methods of descriptive quantitative and Linear Regression Analysis are used in this study. The variables of inventory conversion period, operating cycle, current ratio, cash conversion cycle and return on equity are considered. Data from 2012 to 2016 was gathered as panel data from 20 firms' annual reports of beverage food and tobacco sector for the analysis. The results expose that, operating cycle has a positive significant relationship however cash conversion cycle negatively related with dependent variable of return on equity, but other variables haven't significant relationship with dependent variable of return on equity. In case of regression analysis result, it says inventory management has 0.158 significant impact on return on equity at 5\% level as a whole model but individually operating cycle and inventory conversion period have significant impact. These findings are useful to the directors and financial management of beverage food and tobacco sector's firms as a useful knowledge for decision makings in this field. So, this sector firms should take great care on all of these measures of inventory management when making policies and developing strategies regarding inventory management of this sector firms to improve their return on equity.
\end{abstract}

Keywords: Inventory management; Return on equity; Beverage food and tobacco sector 


\section{Introduction}

A crucial role plays by Inventory management in the growth and survival of all firms. Generally, inventory literature attentions in procurement and production as primary determinants of company inventory procedure and management. Like that, the Classic policy model represent the trade-off between ordering costs and holding costs outline the transactions approach to inventory management and Economic Order Quantity (EOQ) models of inventory developed many decades ago. According to Koumanakos (2008). "In recent years, as the field of operations management has developed, many new concepts have been added to the list of relevant inventory control topics".

In the inventory management literature, several studies have been carried out regarding maintaining inventory level in a firm has been widely studied nonetheless still there is contradiction in viewing inventory as both an asset and a liability. Past studies literature also produced contradictory results regarding this inventory management-financial performance relationship. Noticeably, though negative relationship between inventory and firm performance has been reported by many others those are based on either archival or investigation data ( Fullerton et al., 2003, Elsayed, 2015, Elsayed and Wahba, 2016).

Study of Deloof (2003) explores as "number of inventories days have a significant negative relation on gross operating income". Boute et al. (2006), disclose through their study that, "higher probability for high inventory ratio companies to be bad financial performers". Shah and Shin (2007) studied and disclose that reducing inventories has a significant and direct relationship with financial performance". Milgrom and Roberts (1988) and Dudley and Lasserre (1989) also found in their study negative relationship between profitability and inventories.

Based on these above empirical studies' findings on the field of microeconomic determinants and significances of inventories are slightly inconsistent, so in this study researcher attempt to make further concentration on this issue by engaging additional cultured linear method used with a latest sample at Sri Lankan Beverage Food and Tobacco Companies.

\section{Study Objective}

This research objects to find the inventory management impact on return on equity of Sri Lankan beverage, food and tobacco sector firms listed in Colombo Stock Exchange (CSE). 


\section{Research Questions}

Q1: What is the relationship between inventory management measures and return on equity of beverage food and tobacco sector listed companies?

Q2: Do inventory management measures have an impact on return on equity of beverage, food and tobacco sector listed companies?

\section{Significance of the Study}

This research supports to understand shareholders about the impact of inventory management on return on equity in beverage, food and tobacco sector firms, and expect it will helpful to technical persons to employ efficient control techniques in order to enhance works of this listed firms for maximize the performance. Furthermore, study adds some more knowledge to the literature regarding the inventory management and return on equity in Sri Lankan beverage food and tobacco sector companies.

\section{Inventory Management - Theoretical Foundations}

\subsection{Inventory convention period}

Inventory convention period (ICP) means that the average time that a business holds their inventory (Shin and Soenen, 1998). It can be calculated by (Average inventory / Cost of goods sold) $* 365$. That means the time duration of obtaining materials for a product, manufacture it and sell it. The inventory conversion period is fundamentally the time period during which a firm must invest cash while it converts materials into a sale. Deloof (2003) explores as "keeping best inventory amount diminishes the cost of possible disruptions or business loss because of shortage of products, decreases delivery costs, and safeguards for price fluctuations. The period of inventory conversion has a negative impact on a firm's profitability. A similar study by Raheman and Nasr, (2007) strongly recognized that, negative relationship for inventory turnover and firm's performance.

\subsection{Currentratio}

It measures a company's ability to meet short-term outstanding with current assets. Normally a higher current ratio is welcomed due to the importance of liquidity for success. Nevertheless a very high ratio may suggest that funds are being tried up and may not be earning high returns. According to Gitman (2002), "The current ratio should be between 1.5 and 2 to 1 however it can vary depending upon the business that 
the company is engaged in". Currents ratio can be calculated as Current Assets divided by Current Liability. This might also have impact on profitability, and therefore it must be controlled to avoid it from impairing the study.

Panigrahi (2013) carried out a research to find out the relationship of inventory management on profitability. This research performed regression to determine the current ratio impact on profitability variables. The results indicate as current ratio has significant negative impact on profitability,high current ratio indicates high liquidity position in the organization. It would be more cash or inventory. High inventory, guide to the high accounting profitability. Therefore concerning current ratio is important for this research. After considered above statement, researcher can find out that there was a negative relationship among the current ratio and profitability. But it is not relevant to the all researches. Because it would be change relevant with other factors.

\subsection{Operating cycle}

Obaidullah Jan (2001) says as "Operating cycle is the number of days a company takes in realizing its inventories in cash. It equals the time taken in selling inventories plus the time taken in recovering cash from trade receivables. It is called operating cycle because this process of producing/purchasing inventories, selling them, recovering cash from customers, using that cash to purchase/produce inventories and so on is repeated as long as the company is in operations".

Company's operating efficiency and working capital management measured by the Operating cycle. Napompech (2012) says as "Normally it takes more time to receive the cash which affects negatively to the profitability but it can be improved through reducing no of days in receivables".

\subsection{Cash conversion cycle}

It means a time period (in number of days) that it takes for a firm to convert its inventory and other investments in resources into cash flows. The cash conversion process gives insight into the financial stability of a company because it reflects the time period during which assets are committed to business processes and therefore are not available to invest to achieve even greater returns. As a result, the shorter the cash conversion cycle, the better.

Journal of Business Studies, 7(2)

$-119-$

2020 
Belt (1979) explores "Cash inflow and cash outflow are two have much importance in measuring the performance of the organizations". Mappanyuki and Sari, (2017) revealed that "Organizations expect a negative relationship between the cash conversion cycle and profitability of the organizations but some studies also found a positive relationship of cash conversion cycle with profitability". Afza and Nazir, (2007) conducted a research with the Karachi Stock Exchange listed firms sample on, and Abuzayed, (2012) carried out with the Amman Stock Exchange listed firms sample; both of them found that lower cash conversion cycle improves the performance. So this research study tries to analyze furthermore regarding this matter also.

Through reviewed these above studies (Raheman \&Nasr, 2007; Napompech, 2012; Abuzayed, 2012; Mappanyuki \& Sari, 2017), this study selected the inventory management measures as cash conversion cycle, current ratio, inventory conversation period \& operating cycle.

\section{Return on Equity}

Return on equity (ROE) is a ratio between the net profit after tax and total equity. In other words, the return on equity ratio shows how much profit each rupee of common stockholders' equity generates. Return on equity ratio is a measure of earnings available to owners of the firm (common shareholders \& preferred shareholders) on the capital that they (owners) invested in that firm. Further it is commonly used as a profitability indicator of the firm too.

Profitability is the capacity of the company makes a profit in relation to their sales, total assets and own capital. (Warfield, 2011) says as "profitability ratio is a ratio that illustrates the company's ability to earn a profit through all the existing capabilities and resources such as sales activities, cash, capital, number of employees, number of branches and so on". According to Brigham and Houston (2009) "profitability is the end result of a number of policies and decisions by companies". Return on equity is an important indicator to measure the efficiency of management in using the equity finance to fund operations and growth of the firm. Potential investors always want to know how efficiently firms use their money to generate net income in this way return on equity is an important measurement for them. 
Hence return on equity is considered as dependent variable and examining the effects of inventory conversation period, current ratio, operating cycle and cash conversion cycle on return on equity in this study.

\section{Hypotheses Development}

According to the above conversation on theoretical basis and earlier studies, it can be seen that the greatness of each Inventory management measure affect the return on equity. To clarify the discussion that has been done, the following hypotheses formulated;

Hypothesis 1: Inventory management measures have a significant relationship with return on equity of beverage, food and tobacco sector listed companies in Sri Lanka Hypothesis2: Inventory management measures have an impact on return on equity of beverage, food and tobacco sector listed companies in Sri Lanka.

\section{Research Design}

This research is investigated the effects of the inventory management measures (independent variable) on return on equity (dependent variable) after occurrence. The study used descriptive research design and applied regression analysis to describe the effects of inventory management on return on equity. This research design was chosen the descriptive method also as an effective tool. Thuvarakan (2012), "says that, the use of descriptive analysis helps the researcher avoid the difficulties of getting clear understanding about the data collected and its pattern over the years". To effectively apply the descriptive analysis, the Stata 14 package was selected to analyze the panel data for the variables.

\section{Regression Model}

The author developed the bellow regression model for this study to analyses the collected data

$\mathrm{ROE}=\alpha+\beta 1(\mathrm{CR})_{\mathrm{it}}+\beta 2(\mathrm{CCC})_{\mathrm{it}}+\beta 3(\mathrm{ICP})_{\mathrm{it}}+\beta 4(\mathrm{OC})_{\mathrm{it}}+\mathrm{e}_{\mathrm{it}}$

Where:

$\mathrm{ROE}=$ Return on Equity

$\mathrm{CR}=$ Current Ratio

$\mathrm{CCC}=$ Cash conversion cycle

$\mathrm{ICP}=$ Inventory Conversion Period

Journal of Business Studies, 7(2)

$-121-$

2020 
$\mathrm{OC}=$ Operating cycle

$\mathrm{a}=$ intercept

$\mathrm{e}_{\mathrm{it}}=$ error

The regression model was selected for the reason that this is recognized as a well fit instrument to describe the relationship between independent and dependent variables. Further, in this study independent variable of inventory management and independent variable of profitability relationship could be reasonably assumed to be linear. In the past many authors used this model in their studies like Raheman and Nasr, (2007), Makori \& Jagongo, (2013), Hina, Mba and Mphil (2014) and Jayarathne (2014).

\section{Reliability and Validity}

There is not much difference in the reporting systems among the listed companies as they mostly followed the Accounting Standards by the requirement of the Accounting and Auditing standards Act No. 15 of 1995 of Sri Lanka. According to the CSE regulations all the firms are required to submit their annual reports as requirements of the information disclosure by law. Furthermore, Colombo stock exchange data base keeps the annual reports of listed firms which are audited by qualified charted accountants, hence the collected data from such financial statements and annual reports are more reliable. Study used the pertinent data extracted from the financial statement such as income statements and balance sheets of these listed firms.

Validity means the accuracy and relevance of inferences, which might be primarily constructed on the research outcomes. Mugenda (1999) state as "It is the degree to which results received from the analysis of the data actually represent the variables of the observation".

\section{Data Analysis}

Once the data have been collected, they were scrutinized and the collected data from the annual reports was classified and analyzed by using well known statistical package of Stata 14. Tables were used for purposes of analyzing and presenting the descriptive findings of the study. Variance inflation factor was carried out to diagnose the multicollinearity effect among the descriptive variables.

Correlation analysis performed to determine the strength of associations between the study variables. Coefficients are calculated for the selected beverage, food and Tobacco listed companies. Liner regression was performed to find the impact of independent variables over dependent for the hypotheses testing purpose. 


\section{Population and Sample}

Twenty-one companies were listed in beverage, food and tobacco sector in CSE. As a purposive Sampling, from them twenty companies were selected for 2012 to 2016 to achieve a balanced panel.

\section{Results and discussions}

Table 1 elucidates the statistical distribution of dependent and independent variables of this study.

Table 1: Statistical Distribution (2012- 2016)

\begin{tabular}{llllll}
\hline Var & Ob & Mean & S. Dev. & Mini & Max \\
\hline CR & 100 & 2.948528 & 5.391127 & .1167155 & 45.65175 \\
CCC & 100 & 8.72313 & 228.4558 & -1465.523 & 1536.297 \\
ICP & 100 & 63.6043 & 50.59704 & 10.12273 & 295.5786 \\
OC & 100 & 171.2038 & 108.8892 & 54.82003 & 443.4706 \\
ROE & 100 & 37.28268 & 89.1532 & -4.026108 & 670.1446 \\
\hline
\end{tabular}

The above statistics of the independent and dependent variables reveal numerous issues. Mean (average) return on investment (ROE) is $37.28 \%$ to the entire sample at the same time standard deviation recorded as 89.15 . This ROE measure is applied as a profitability of the firm, which is varying from -4.02 to 670.14 with mean value of $37.28 \%$, and explicates that firms of this sector have a normal performance. The variance in return on equity extended from profitability ratio of $670.14 \%$ (max) to $4.02 \%$ (mini). It realizes there is a big difference in profitability of this sector firms.

From these inventory management measures of this study, OC has a highest average ratio of 171.2 it indicates that, averagely a company takes 171 days to realizing its inventories as cash in this sector companies. CR indicates as lowest average ratio of 2.95 it means an average short-term solvency situation is 2.95 times in this sector companies. More than that, CCC and ICP have 8.72 and 63.60 respectively.

This study notices that, the most volatile variable is cash conversion cycle among these examined variables with the standard deviation value of 228.46 then operating cycle and inventory conversion period following that with standard deviation of 108.89 and 50.6 respectively. While the most stable variable is current ratio with the standard deviation of 5.39. 


\subsection{Correlation matrix}

ROE takes significant relationship with operating cycle, which is $29.14 \%$ at $05 \%$ significant level, whereas the next inventory management measure of inventory conversation period also has a positive low degree of strength relationship with $19.17 \%$ but insignificant at $05 \%$ level. At the same time the other two inventory management measure of CCC and CR are correlated with ROE $-10.43 \%$ and $-19.12 \%$ respectively, but CR insignificant at $05 \%$.

Thus, it can say OC has a positive influence with ROE and cash conversion cycle has a negative influence with ROE and both are significant at this sector Companies. This result is consistent with Lyroudi and Lazaridis (2000), Abuzayed (2012) and Takon, (2013) but not consistent with Nadeem et al., (2017).

Any how it is important to note that these descriptive statistics values and correlation analysis values are just point out the associate link between related variables. These values even they have with high coefficient values, don't essentially establish a causal relationship. Therefore, a more advanced and exact techniques are needed for the satisfactorily capture of definite significant influence between the dependent and independent variables.

Table 2: Correlation Matrix and VIF for of 2012 -2016

\begin{tabular}{lcccccc}
\hline & ICP & CR & OC & CCC & ROE & VIF \\
\hline ICP & 1.0000 & & & & & 2.29 \\
CR & $0.2798^{*}$ & 1.0000 & & & & 2.06 \\
OC & $0.6319^{*}$ & -0.1438 & 1.0000 & & & 1.38 \\
CCC & $-0.3266^{*}$ & 0.1372 & $-0.3451^{*}$ & 1.0000 & & 1.21 \\
ROE & 0.1917 & -0.1043 & $0.2914^{*}$ & $-0.1912^{*}$ & 1.0000 & \\
\hline
\end{tabular}

. * -Significant at $05 \%$ level

Usually when doing the regression analysis the statistical problem among the independent variables of multicollinearity issue should be considered. Gujarati, (2003) recommend VIF to diagnostics the multicollinearity issues among the independent variables. 
VIF values among the independent variables are measured and presented in the Table 2 and that indicates no any value of VIF above to 3 (cutoff $<10$ ) it shows there is no any multicollinearity issues amongst the independent variables of this study.

\subsection{Regression result}

This analysis examines independent and dependent variables' relationship and their strength. Analyzed result presented in Table 3.

\section{Table 3: Regression result}

\begin{tabular}{lcccc}
\hline ROE & Coefficient & SE & $\boldsymbol{t}$-statistic & Prob. \\
\hline ICP & .069875 & .2596146 & 0.27 & 0.788 \\
CR & -1.16705 & 1.895372 & -0.62 & 0.540 \\
OC & .1840413 & .1145635 & 1.61 & 0.111 \\
CCC & -.0355153 & .0417547 & -0.85 & 0.397 \\
Constant & 5.080662 & 18.17963 & 0.28 & 0.780 \\
\hline
\end{tabular}

Note: $R^{2}=0.0979 ;$ Adjusted $R^{2}=0.0599 ; F(4,95)=2.58 ;$ Prob $>F=0.042$

As per the results of regression result in Table 03, this regression results have a $\mathrm{R}$ square value is 0.0979 that designates the explanatory influence of the inventory management measures to ROE. It means $09.79 \%$ of the difference in return on equity of this sector companies are explained through this inventory management which is represent by the ICP, CR, OC and CCC; while $90.21 \%$ is described by others factors to this model. As a whole model this is a significant model at 5\% level, but individually all of these variables are insignificants. Because of this, fixed, random effect models and Hausman test were performed to find out the most appropriate model for this study. According to the Hausman test value of Prob $>$ chi $2=0.0220(p<0.05)$, fixed effect model was selected as most appropriate. Fixed-effects (within) regression result achieved and presented in Table 4 . 
Table 4: Fixed-effects (within) regression result

\begin{tabular}{lcccc}
\hline ROE & Coefficient & SE & $t$-statistic & Prob. \\
\hline ICP & -.5959799 & .2931667 & -2.03 & 0.046 \\
CR & .6497713 & 1.924008 & 0.34 & 0.737 \\
OC & .5312654 & .1429327 & 3.72 & 0.000 \\
CCC & .0138594 & .0363855 & 0.38 & 0.704 \\
Constant & -17.80183 & 23.82948 & -0.75 & 0.457 \\
sigma_u & 71.457329 & & & \\
sigma_e & 63.971475 & & & \\
rho & .55510683 & (fraction of variance due to u_i) \\
\hline
\end{tabular}

Note: $R^{2}=0.1585 ; F(4,76)=3.58 ;$ Prob > F = 0.0100; corru_i, $\left.X b\right)=-0.3262$

$\mathrm{R}$ square is 0.1585 in this Fixed-effects regression model and adding to new variable, it will explain $15.85 \%$ of the return on equity. This noticed that, this model is a significant predictor ( $\operatorname{Prob}>\mathrm{F}=0.0100$ ), furthermore there is positive relationship between inventory management and ROE.

Considering the $\mathrm{P}$ value for each inventory measure, for inventory conversation period it is 0.046 which indicates that ICP is significant variables at $5 \%$, And this relationship is negative (-.5959). When considering current ratio's $p$ value that is 0.737 which indicates that $\mathrm{CR}$ insignificant variables at $5 \%$ confidence level. At the same times, OC positively related with return on equity with the p-value of 0.000 and significant at level of 0.05 . CCC positively related with ROE but insignificant with the p-value of 0.704 at $5 \%$ level. Based on this result of dependent variable return on equity realizes that, statistically it is a well fitted model as an overall model. Since to this return on equity $\mathrm{F}$ value of model (0.0100) indicates it is a significant model at $5 \%$ level confidence. The fixed effect model estimation as follows,

$\mathrm{ROE}=-17.80-0.595 \mathrm{ICP}+0.649 \mathrm{CR}+0.531 \mathrm{OC}+0.013 \mathrm{CCC}$

It shows that the ROE is always depend on a constant factor of -17.80 regardless of the existence of other ROE determinants factors. Each unit increases in ICP has a negative impact on ROE with the value of $59.59 \%$, each unit increases in CR will increase the ROE by 0.64 , every unit increase of OC will increase $53.1 \%$ on ROE and every unit 
increase of CCC will increase the ROE by 0.0138 , at the same time, independent variables of $\mathrm{CR}$ and $\mathrm{CCC}$ of this model are individually insignificant at $05 \%$ level. Thus, the null hypotheses rejected and alternative hypotheses of $\mathrm{H} 1$ and $\mathrm{H} 2$ are accepted in case of ICP and OC only in Sri Lankan Listed beverage food and tobacco companies.

\section{Conclusions of the Study}

A noteworthy similarity between the independent variable of inventory management measures influences on firms' profitability in Sri Lanka by developed nations and dissimilarity with some developing nations' firms is that, Sri Lanka firm's most possibly operating cycle positively influence on return on equity. Additional to these disclosures that, Sri Lankan firm's effect of operating cycle is higher. According to the findings of inventory management measures have positive influence on return on equity. Further this model says that, as a whole model selected four inventory measures have significant impact on dependent of the return on equity at $5 \%$ level. This findings consistent with Anichebe \& Agu (2013) and Syed, et al (2016).

This findings recommend that a few numbers of insights from western developed theories can be convenient to Sri Lanka also, more than that the certain specific aspects of firms those are relating with inventory management measures and firms' profitability in developed nations are also relevant to Sri Lanka.

\section{Recommendations}

Consistent to these results of this research, the subsequent suitable recommendations are specified as; beverage, food and tobacco Sri Lankan listed firms would attempt to keep higher operating cycle and less inventory conversion period those can help to increase returns on equity.

\section{Contribution to Knowledge}

These findings contribute to the existing knowledge through this research of inventory management measures that are influenced on returns on equity of beverage food and tobacco sector listed firms of Sri Lanka, based on the view of inventory management measures of the firm. This research assists to know the inventory management measures impact on returns on equity of beverage food and tobacco sector. These results might be supported to the Board directors and financial executives of this 
sector firms as assist a convenient database and source materials for the inventory management and firms' profitability field decision.

\section{Recommendations for Further Studies}

This study has placed some keystone by surveying the influence of inventory management practices on firm's profitability leading which a more thorough assessment of beverage, food and tobacco Sri Lankan listed firms. Furthermore, it proposed to estimate the relationship between inventory management and firm's profitability using the data including other unlisted firms too. More than that, further work is required to design with new variables and develop new hypotheses to reflect the relationship of inventory management with firm's profitability. In addition, a more detailed effort that studies the effects of the other sector wise detailed work and ongoing economic and political downturn on inventory management and firm's profitability of Sri Lankan firms might help in solving some theoretical underpinnings of the obtained results of this research study.

\section{Limitations of the Study}

Even though we carried out this study very carefully, we are aware of its limitations and shortcomings. As with most empirical research this research also subject to its limitations.

Initially planned to cover all 21 individual quoted firms in CSE over the period of 2012-2016. But recently listed company haven't full 5 years data set, for the purpose of making balanced panel data, only 20 companies which are having the data from 2012 to 2016 were considered. Because, unbalanced panel data is causing some degrees of different weight in results between years.

So, the research was conducted in a limited population of 20 firms listed in CSE in this sector. If it can be done in a larger sample by including not only in this sector listed companies but also other sectors and non-listed companies, it would be better. Furthermore, though listed companies are one of form of incorporated companies but there are many companies running under other forms of incorporated companies in Sri Lanka too. In fact there are other forms of incorporated companies. Therefore, the result may not represent the result on other forms of incorporated companies in Sri Lanka; and implication from this result cannot be applied to the whole. 
The short time period (5 years) covered is also other potential limitation. Increasing the time period covered is an opportunity, even though, technology or industrial or institutional changes over time might cause change of companies' behavior in this case failed to cover large time period could bias the results.

Sri Lankan listed companies are strictly adopting Sri Lanka Accounting Standards. But, apart from that, there is problem with the companies included in the sample set, which have and adopt different accounting policies according to their own accounting manual such as depreciation method and percentages. 


\section{References:}

Abuzayed, B. (2012). Working capital management and firms' performance in emerging markets: the case of Jordan. International Journal of Managerial Finance, 8(2), 155-179. https://doi.org/10.1108/17439131211216620

Afza T and Nazir M S. (2007). Working Capital Management Practices of Firms:Empirical Evidence from Pakistan. In N. S. University (Ed.), Working Capital Management Practices of Firms:Empirical Evidence from Pakistan (pp. 34-343).

Anichebe, N. A., \& Agu, O. A. (2013). Effect of Inventory Management on Organisational Effectiveness. In Information and Knowledge Management, $3(8), 92-100$

Belt, B. (1979). Working capital policy and liquidity in the small business. Journal of Small Business Management, 17(3), 43-51.

Boute, R., Lambrecht, M., Lambrechts, O., \& Sterckx, P. (2006). An analysis of inventory turnover in the Belgian manufacturing industry, wholesale and retail and the financial impact of inventory reduction, in Proceedings of the 14th 2006 EurOMA conference, Strathclyde, June.

Brigham. F. E. \& Houston. F.J. (2009), Fundamentals of Financial Management, Twelfth Edition, South-Western Cengage Learning.

Deloof, M. (2003). Does working capital management affect profitability of Belgian firms? Journal of Business Finance and Accounting, 30(3/4), 573-588.

Dudley, L. and Lasserre, P. (1989), Information as a substitute for inventories, European Economic Review, 33, 67-88.

Elsayed, K. (2015). Exploring the relationship between efficiency of inventory management and firm performance: An empirical research. International Journal of Services and Operations Management, 21 (N.1), 73-86.

Elsayed, K., \& Wahba, H. (2016). Reexamining the relationship between inventory management and firm performance: An organizational life cycle perspective. Future Business Journal, 2, 65-80.

Fullerton, R.R., McWatters, C.S., \&Fawson, C. (2003) An examination of the relationships between JIT and financial performance Journal of Operations Management, 21(4), 383-404. 
Gitman, L. J. (2002). Principles of Managerial Finance. Addison Wesley, 2002.

Gujarati, D. N. (2003). Basic Econometrics. McGraw Hill, 2003.

Hina, A., Mba, and Mphil. (2014) Impact of working capital management on profitability. European Scientific Journal, 10(1), pp1857-7881.

Jayarathne, T.A.N.R., (2014). Impact of working capital management on profitability: Evidence from listed companies in Sri Lanka. Proceeding of the 3rd International Conference on Management and Economics, Oral Presentations. pp: 269-274.

Khaled Elsayed, Hayam Wahba( 2016). Reexamining the relationship between inventory management and firm performance: An organizational life cycle perspective, Future Business Journal, Vol. 2(1), pp 65-80.

Koumanakos Dimitris. (2008). The Effect of Inventory Management on Firm Performance. International Journal of Productivity and Performance Management. 57.355-369. 10.1108/17410400810881827.[1]

Lazaridis I, Tryfonidis D, (2006). Relationship between working capital management and profitability of listed companies in the Athens stock exchange. Journal of Financial Management and Analysis, 19, pp 26-25.

Lyroudi, \& Lazaridis. (2000). The Cash Conversion Cycle and Liquidity Analysis of The Food Industry in Greece. Business and Economics Society International. Available at SSRN: https://ssrn.com/abstract=236175 or http://dx.doi.org/10.2139/ssrn.236175

Makori, D. M., \& Jagongo, A. (2013). Working Capital Management and Firm Profitability? Empirical Evidence from Manufacturing and Construction Firms Listed on Nairobi Securities Exchange, Kenya. 1(1).

Mappanyuki, R., \& Sari, M. (2017). The effect of sales growth ratio, inventory turnover ratio, growth opportunity to company's profitability (survey in Indonesia's stocks exchange). International Journal of Management and Applied Science, 3(3), 139-147.

Milgrom, P. and Roberts, J. (1988). An economic approach to influence activities in organizations, American Journal of Sociology, Vol. 94, 154 - 79.

Mugenda, A. G. M. (1999). Research Methods: Quantitative and Qualitative Approaches. African Centre for Technology Studies, 1999. 
Nadeem, M., Atta, S., Javed, H., Ahmad, I., \& Jawad Khalil, M. (2017). Relationship between Working Capital and Corporate Performance in the Textile Sector of Pakistan. International Journal of Family Business and Management, 1(1), 1-5. https://doi.org/10.15226/2577-7815/1/1/00106

Napompech, K. (2012). Effects of Working Capital Management on theProfitability of Thai Listed Firms. International Journal of Trade, Economics and Finance, 3(3), 227-232.https://doi.org/10.7763/ijtef.2012.v3.205

Obaidullah Jan (2001). Referenced at https://accountingexplained.com/financial/ ratios/operating-cycle

Panigrahi A.K. (2013), "Negative Working Capital and Profitability - An Empirical Analysis of Indian Cement Companies", International Journal of Research in Commerce and Management, published by IJRCM, pp 41 -45 .

Raheman, A., \& Nasr, M. (2007). Working capital management and profitability case of Pakistani firms. International Review of Business Research Papers, 3(1), 279300.

Shah, R. \& Shin, H. (2007), Relationships among information technology, inventory, and profitability: an investigation of level invariance using sector level data, Journal of Operations Management, 25(4), 768-784.

Shin H. and L. Soenen (1998) Efficiency of Working Capital and Corporate Profitability, Journal Financial Practice and Education, Vol. 8, pp 37-45.

Syed, S. J.A. N., Mohamad, N. N. S., Rahman, N. A. A., \& Suhaimi, R. D. S. R. (2016). A Study on Relationship between Inventory Management and Company Performance: A Case Study of Textile Chain Store. Journal of Advanced Management Science, 4(4) pp. 299-304.

Takon, S. M. (2013). Does Cash Conversion Cycle Have Impact on Return on Assets of Nigerian Firms? 4(14), 34-43.

Thuvarakan, Senthilmani. (2013). Impact of Working Capital Management on Profitability in UK Manufacturing Industry. Available at SSRN: https://ssrn.com/abstract $=2345804$

Warfield, D.(2011). Intermediate Accounting. John Wiley \& Sons. 